\title{
EPISTEMOLOGI PENEMUAN HUKUM NAHDLATUL 'ULAMA (NU)
}

\author{
Ibnu Elmi A.S. Pelu
}

\begin{abstract}
The dynamics of the spirit of ijtihad religious organizations in Indonesia continues to run. Nahdlat al-' Ulama or NU as a religious organization initiated by KH. Hashim Ash'ari, KH. Hasbullah and KH Wahab. Bisri Samsuri on January 31, 1926 in East Java also has a style and epistemology ijtihad unique to observe

This paper reveals the epistemological model of ijtihad or istinbat al-Ahkam NU. epistemology istinbat al-Ahkam NU using methods ilhaq al-masa'il bi nazairiha. Ilhaq almasa'il bi nazairiha is to equate the law of a case that does not exist, the books of fiqh as a reference, by the law of a similar issue that has been answered by the text in these books to be based on the elements/pillars ilhaq inside it. Ilhaq epistemology is a modification of the theory of qiyas and pillars inside. Only difference, ilhaq has elements/pillars, namely mulhiq, mulhaq 'alaih, mulhiq law and' illat al-hukm. If qiyas was based on the Qur' an and Sunnah, while ilhaq resting on the books of fiqh existing mains.
\end{abstract}

Keywords: epistemology, ijtihad, NU

\section{A. Latar Belakang Masalah}

NU atau Nahdlatul'Ulama'sensitif menyoroti persoalan-persoalan aktual di masyarakat. NU sebagaisalah satu organisasi keagamaan di Indonesia, bergerak dalam berbagai bidang,baik ekonomi, hukum, pendidikan, dakwah islamiyyahdan lain-lain. Dalam memecahkan problem yang ada, NU memiliki corak, model epistemologi dan akar pemikiran tersendiri dalam dalam mekanisme penetapan hukum atau istinbat alahkam.Para Kiyai NU,mendasarkan karakter pemikiran hukumnya pada dominasi satu madh-hab, yaitu madh-hab Shafi'iyyah. Sejak awal berdirinya, NU juga membuka peluang kepada para Kiyai NU untuk menerobos pandangan madh-hab lain, Selain madhhab anutan khas NU itu, alur dan karakter pemikiran hukum NU yang Shafi'itersebut, tentu saja berpengaruh kepada proses penetapan hukum Islam dikalangan NU selanjutnya.

Diantara aktualisasi dalam prosedur penetapan hukum NU, yaitu eksistensi wadah yang memfasilitasi para Ulama'/Kiyai NU dalam menumpahkan semua gagasan dan ide terhadap masalah yang akan dipecahkan. Wadah atau forum tersebut yaitu LajnahBahtsulMasa'il (selanjutnya disebut LBM).

Semenjak tahun 1926, LBM memiliki peran sentral dalam mekanisme penetapan hukum NU terhadap masalah waqi'ah yang terjadi dimasyarakat.Sudah tak terhitung jumlah fatwa yang sudah dicari hukumnya melalui forum ini.

Yang lebih manarik lagi untuk dikaji, yaitu bagaimana mekanisme penetapan hukum di dalam forum LBM.Di dalam forum LBM dapat dilihat bagaimana prosedur istinbat hukum dari Ulama'/Kiyai NU. Di dalam forum tersebut, terjadi pengkajian 
mendalam terhadap masalah-masalah aktual yang perlu di cari hukumnya, yang tentu saja dihujani berbagai fighting ideas dari seluruh peserta.

Adapun untuk mengkaji berbagai problematika yang ada,hingga terbentuknya sebuah produk hukum, NU memiliki dan menggunakan metode istinbat al-ahkam. Seperti apa metode yang digunakan, tentu saja sangat dipengaruhi oleh kerangka berfikir penggagasnya dan budaya masyarakat kultural/tradisional.

Seperti apa corak pemikiran hukum NU, sehingga mempengaruhi proses penetapan hukum didalamnya, serta bagaimana metode penetapan hukum melalui LBM tersebut ?inilah yang menjadi motiv penulis untuk mengangkat masalah ini, dengan tema Prosedur istinbat al-ahkam NU.

\section{B. Sejarah Singkat Lahirnya NU}

NU merupakan singkatan dari Nahdah al-Ulama'.Nahdah al-Ulama' berasal dari kosa kata arabNahdah yang berarti bangkit, sedangkan al-Ulama' merupakan bentuk jama' dari kata 'Alim yaitu orang yang menguasai ilmu agama secara mendalam. Jadi, secara harfiyah NU berarti kebangkitan para Ulama'.

Dalam perkembangannya, NU mengalami sejarah dan perjalanan yang berliku dan panjang.NU didirikan oleh KH. Hashim Ash' ${ }^{2},{ }^{2}{ }^{2}$ KH. Abdul Wahab Hasbullah dan KH. Bisri Samsuri. Mengenai latar belakang berdirinya NU, ada beberapa pendapat tokoh antara lain seperti menurut Ja'far Shodiq, ${ }^{3}$ bahwa pada mulanya, NU merupakan kelanjutan dari komite Hijaz yang berkepentingan untuk melindungi praktik keagamaan tradisional. Sedangkan menurut Muhammad Fajrul Falah, ${ }^{4}$ salah seorang tokoh muda NU, merangkum tiga alasan pokok berdirinya NU: pertama, aksi kultural untuk bangsa, yakni menggunakan strategi akulturasi dengan budaya setempat, dalam memperkenalkan Islam pada masyarakat. Kedua, aktivitas yang mencerminkan dinamika berfikir kaum muda.Ketiga, usaha membela keprihatinan keagamaan internasional, yakni munculnya gerakan wahabiyah ${ }^{5}$ yang berusaha menghilangkan segala khurafat, bid'ah yang ada dikota suci Makkah. Untuk alasan yang terakhir, ide ini munculdari pemikiranshaikh Muhammad bin 'Abd al-Wahab. ${ }^{6}$ Beberapa ide-ide kotraversial yang ada dalam aliran wahabiyah, ${ }^{7}$ antara lain :

${ }^{1}$ Ja'far Shodiq, Pertemuan antara Tarekat dan NU, Studi hubungan Tarekat dan Nahdlatul Ulama' dalam Konteks Komunikasi Politik 1955-2005, (Yogyakarta: Pustaka Pelajar, 2008), 54.

${ }^{2}$ Dedy Djamaluddin Malik, at., al, Zaman Baru Islam Indonesia: Pemikiran dan Aksi Politik Abdurrahman Wahid, M. Amin Rais, Nurchalish Madjid, dan Jalaluddin Rakhmat, (Bandung: Zaman Wacana Mulia, 1998), 81.

${ }^{3}$ Ibid., 67.

4 Imam Yahya, Bahthu al-Masa'il NU: Media Pemikiran Hukum Islam. Dalam http://buntetpesantren.org.(28 Mei 2009).

${ }^{5}$ Wahabi adalah organisasi yang murni bergerak dibidang keagamaan, bukan organisasi politik. Gerakan ini bergulat dengan persoalan keagamaan internal umat Islam, terutama paham tauhid kaum muslimin yang telah dipengaruhi ajaran tarekat, sehingga menghargai peran Imam tarekat sebagai wali dan memuliakan makam mareka. Disamping tarekat, tradisi-tradisi keagamaan lainnya juga dianggap menyimpang dari shari'at Islam.Gerakan ini sangat radikal-puritan dan tidak kenal kompromi terhadap ajaran-ajaran yang tidak islami, dan takhayyul yang dikaitkan dengan ajaran tersebut. Lihat: M. Ali Haidar, NU dan Islam di Indonesia; Pendekatan Fikih dalam Politik, (Jakarta: PT. Gramedia Pustaka Utama, 1994), 118.

${ }^{6}$ Muhammad bin 'Abd al-Wahab adalah pendiri aliran wahabi. Beliau dilahirkan di Desa Uyaynah dekat kota Riyad (1703-1792 M). Beliau mendapat pendidikan agama dari ayahnya sendiri, yaitu shaikh 'Abd al- 
1. Bahwa, berziarah ke makam Rasulullah saw merupakan perbuatan haram dan mendatangkan dosa. Ia lebih jauh berpendapat, bahwa barangsiapa berziarah ke makam Rasulullah saw, mereka tidak boleh meng-qasar salatnya saat dalam perjalanan karena tujuan perjalanannya adalah untuk berbuat dosa. Ia menyandarkan pendapatnya ini pada hadith Rasulullah saw :

Artinya: "Janganlah bersusah payah melakukan perjalanan, kecuali ke tiga masjid: mesjidku ini, Mesjidil Haram dan Mesjid al-Aqsa." (HR. Bukhari Muslim dari Abu Hurairah).

Ia memahami hadith ini, bahwa Rasulullah saw melarang bersusah payah melakukan perjalanan ke tempat lain selain tiga mesjid tersebut, termasuk berziarah ke makam beliau saw. Sementara madh-hab-madh-hab yang lain menganggap bahwa subyek hadith tersebut terkait dengan ziarah ke masjid-masjid, sementara berziarah ke makam Rasul tergolong perbuatan mandub didasarkan pada hadith :

Artinya : "Dahulu aku melarang kalian berziarah. Maka sekarang berziarahlah." (HR. Muslim, Ibnu Majah, Malik, Ahmad dan Turmudzi dari Buraidah).

2. Ia tidak cukup dengan menetapkan ibadah sebagaimana yang ditetapkan Islam di dalam al-Qur'an dan al-Sunnah, menurut pandangan Ibnu Taimiyyah, dalam tradisipun tidak boleh keluar dari lingkup Islam sebagaimana persepsinya. Oleh karenanya ia mengharamkan rokok, kopi, musik/qasidah, membuat kubah-kubah mesjid, fotografi makhluk hidup dan sebagainya.

3. Ia memperluas pengertian bid'ah mulai dari aktivitas-aktivitas yang dianggap ibadah mandub oleh sebagian kalangan Ahlu al-Sunnah, seperti membaca tawasul, membaca al-Qur'an dengan qira'ah fuqaha', membaca kitab salawat dalail al-khairat yang dianggap terlalu memuju-muji Rasulullah saw, mengkaji "sifat duapuluh" sebagaimana ajaran Ash'ari, mengamalkan tarekat, peringatan Maulid dan lain-lain hingga kepada hal-hal yang tidak menyangkut ibadah, seperti memasang kain penutup Raudah, membuat kubah mesjid, dan lain-lain.

4. Yang paling memunculkan perbenturan adalah gerakannya yang-sebagaimana diajarkan Ibnu Taymiyah- berlawanan dengan mainstream pemikiran masa itu yang cenderung didominasi oleh metode berpikir filsafatis (mantiqi), seperti aliran pemikiran Ash'ariyyah/Maturidiyyah dan Mu'tazilah,serta gerakan tasawuf yang dianggap terlalu mengagungkan perasaan dan khayalan dalam beragama.

5. Wahabi juga menyerang budaya taklid kepada madh-hab (termasuk dalam hal furu') sebagaimana juga gagasan Ibnu Taymiyah.

6. Ia melakukan pendekatan dakwah dengan kekerasan dan senjata yang dipandang wajib dalam rangka menegakkan Sunnah dan memusnahkan bid'ah. Ini terlihat dari gerakannya yang monumental, menghancurkan kuburan para shahabat Nabi serta situs-situs sejarah Nabi dengan alasan mencegah pemujaan terhadap tempat-tempat tersebut.

Wahhab dan menimba ilmu dari beberapa shaikh dan ulama besar, semisal shaikh Muhammad Hayat al-Sindi, penulis Hashiyah Sahih Bukhari, dan belajar kepada shaikh Muhammad Sulaiman al-Kurdi guru shaikh Muhammad Arshad al-Banjari, Martapura, Kalimantan Selatan. Selain belajar kepada mereka, Muhammad bin 'Abd al-Wahab juga mempelajari karya-karya Ibnu Taymiyah dan buku-buku Madh-hab Ibnu Hanbal.

${ }^{7}$ Imam Muhammad Abu Zahrah, Aliran Politik dan Aqidah dalam Islam, (Jakarta: Logos, 1996), 250. 
Merebaknya gerakan purifikasi dan pembaharuan Islam seperti ini, tidak hanya dimotori wahabi 'Abd al-Wahab (1703-1792), tetapi berlanjut oleh kemunculan ide Pan Islamisme oleh Jamaluddin al-Afghani (1838-1897). Gerakan pembaharuan Islam semakin berkembang dan melaju kencang, ketika dilanjutkan oleh murid-murid Jamaluddin al-Afghani, seperti Muhammad 'Abduh (1849-1905) dan Muhammad Rashid Rida (1865-1935). Kencangnya angin pembaharuan ini, akhirnya turut mengilhami beberapa elite muslim Indonesia untuk melakukan reformasi Islam di tanah air. ${ }^{8}$ Inilah faktor yang paling penting, yang melatari lahirnya gerakan-gerakan Islam tradisionalis di Indonesia, termasuk lahirnya NU. Selain alasan tersebut, sejarahlahirnya NU juga dilatarbelakangi oleh keinginan untuk menyelamatkan Makkah dan Madinah dari penguasaan Wahabi yang ekstrem itu, hingga akhirnya NU mengutus Komite Hijaz ke Makah untuk memprotes gerakan Wahabi yang hendak menghilangkan makam Nabi Muhammad SAW, yang dianggap oleh Wahabi sebagai tempat sirik. ${ }^{9}$

Adapun mengenai penggagasnya, NU sebenarnya berdiri atas jasa besar KH. Wahab Hasbullah, yang merupakan sepupu sekaligus murid kepercayaan KH. Hashim Ash'ari. Namun, tanpa izin sang guru tidak mungkin NU dapat berdiri, karena dalam tradisi pesantren, murid atau santri sangat patuh pada guru atau kyainya. Seandainya KH. Hashim Ash' ari melarang KH. Wahab Hasbullah untuk mendirikan NU, bisa dipastikan NU tidak akan berdiri menjadi organisasi massa yang besar hingga kini. Sejarah mencatat bahwa proses berdirinya NU benar-benar tidak banyak bertumpu pada perangkat formal, melaikan lebih bertumpu pada konfirmasi kepada Allah swt. Atas dasar itulah, tepat pada tanggal 31 januari 1926, NU secara resmi menjadi sebuah organisasi atau Jam'iyyah sekaligus gerakan Da'wah al-Islamiyyah dan Ijtima'iyyah. Pada tanggal itu pula ditetapkannya sebagai hari jadi berdirinya NU. ${ }^{10}$

\section{Corak Pemikiran Hukum Islam NU}

Secara umum, akar pemikiran dan gerakan tradisionalisme di Indonesia menganut aliran Shafi' iyyah. ${ }^{11}$ Demikian halnya dengan NU, walaupun dalam beberapa kasus, NU juga berdasarkan pemikirannya pada imam-imam madh-hab lainnya.

Pemikiran bermadh-hab Shafi'iyyah ini, dapat dilihat dari latarbelakang sejarah, seperti, pertama: kuatnya pengaruh adat/budaya dan tradisi masyarakat pada masa sebelumnya. Jika kembali kepada sejarah panjang Indonesia khusunya masuknya Islam ke Indonesia melalui tanah jawa, adalah intergrasi Islam dan budaya masyarakat yang berasimilasi dalam kerangka Islam sufistik.Kedua, dilihat dari sosok penggagas/otak pendiri NU sendiri yang notabene latar belakang kehidupan dan pendidikannya dari dakwah tradisionalis seperti rihlat 'ilmiyyah pesantren kepesantren. ${ }^{12}$ Sementara pesantren sendiri senantiasa berada pada basis pedesaaan yang secara geografis cenderung memiliki

\footnotetext{
${ }^{8}$ Abd. Salam, Sejarah dan Dinamika Sosial Fikih Reformis dan fikih Tradisionalis di Indonesia, dalam Jurnal Islamica, Volume 4, No. 1, (Surabaya: Program Pascasarjana IAIN Sunan Ampel Surabaya, 2009), 50.

${ }^{9} \mathrm{M}$. Ali Haidar, NU dan Islam di Indonesia; Pendekatan Fikih dalam Politik, (Jakarta: PT. Gramedia Pustaka Utama, 1994), 55.

${ }^{10}$ Nurul Hanani, Ijtihad dan Taklid Perspektif KH. Hashim Ash'ari, (Kediri: STAIN Kediri Press, 2009), 55.

11 Rozikin Daman, Membidik NU, (Yogyakarta: Gama Media, 2001), 28.

12 Imam Yahya, Bahtsul Masa'il NU: Media Pemikiran Hukum Islam. Dalam :http://buntetpesantren.org. (28 Mei 2009).
} 
low tradition.Sedangkan secara politis, sebagaimana menurut Ja' far Shodiq, ${ }^{13}$ selain dua faktor di atas, kuatnya tantangan terhadap wahabisme di Makkah, juga menjadi pemicu menguatnya paham-paham yang membela tradisi-tradisi dan budaya masyarakat lokal seperti di Jawa dan Madura.

Jika melihat penjelasan singkat diatas, dapat disimpulkan bahwa corak pemikiran hukum Islam di dalam NU adalah bermadh-hab Shafi'i.Hal ini dapat dibuktikan bagaimana rihlat'ilmiyyah yang dilakukan pendiri NU, serta pemikiran yang mengakomodir kondisi masyarakat berbudaya tradisonal pada waktu itu.Corak Shafi'iyyah juga dapat dilihat kemana para guru-guru pendiri NU belajar. Berdasarkan ini pula, pengaruh madh-hab Shafi'i dalam berbagai pemecahan dan "ijtihad" yang dilakukan, yakni senantiasa menjadi manhajNU dibidang hukum Islam, sehingga dalam menyelesaikan masalah-masalah yang ada dimasyarakat, khususnya warga NU selanjutnya.

\section{Prosedur Intinbat Hukum Islam NU}

Sebelum menjelaskan bagaimana mekanisme dan prosedur istinbat hukum Islam NU, penulis akan membagi prosedur istinbat dalam dua aspek. Aspek tersebut adalah aspek pada prosedur teknis istinbat hukum Islam NU dan aspek pada prosedur penetapan hukum Islam NU.

1. Aspek pada prosedur teknis penetapan hukum Islam NU

Pada aspek ini, prosedur teknis istinbat hukum Islam NU memiliki beberapa perangkat dan struktur formal yang bersifat akomodatif.Penulis menyimpulkan, perangkat-perangkat tersebut antara lain, adalah para Ulama'/Kiyai NU, forum kajian, referensi/kitab rujukan dan objek yang dikaji.

a. Ulama'/Kiyai NU

Ulama' NU yang dimaksud adalah Ulama'/Kiyai NU yang masuk dalam struktur organisasi maupun diluar struktur organisasi.Ulama' yang masuk dalam struktur organisasi seperti Ulama'/Kiyai yang duduk di dewan Shuriyah (legeslatif), sedangkan yang diluar struktur, seperti para pengasuh pondok pesantren, akademisi dan lain-lain.dari segi usiapun beragam, baik tua maupun muda. $^{14}$

b. Forum kajian

Dari segi operasionalnya, NU mempunyai sebuah forum kajian/diskusi. Forum ini tentu menjadi wadah ekspresi dan ajang orasi pemikiran bagi segenap Ulama'/Kiyai dan pihak berwenang dalam NU untuk merepresentasi semua persoalan-persoalan yang akan dipecahkan. Wadah tersebut yakni LajnahBahthu al-Masa'il (LBM/BM).

Secara historis, forum LBM telah ada sebelum NU berdiri.Saat itu sudah ada tradisi diskusi di kalangan pesantren, yang melibatkan Kiyai dan santri.Hasil diskusi tersebut kemudian diterbitkan dalam bulletin bernama LINO (Lailat alIjtima' Nahdah al-Ulama').Dalam LINO, selain memuat hasil BM, juga menjadikan ajang diskusi interaktif jarak jauh antar para Ulama' pada waktu itu.

\footnotetext{
${ }^{13}$ Ja'far Shodiq, Pertemuan antara Tarekat dan NU, Studi hubungan Tarekat dan Nahdlatul Ulama' dalam Konteks Komunikasi Politik 1955-2005, (Yogyakarta: Pustaka Pelajar, 2008), 67.

${ }^{14}$ LTN NU, Solusi Problematika Aktual Hukum Islam, (Surabaya: LTN NU Jawa Timur dan Diantama, 2005), $x$.
} 
Prosedurnya, seorang Kiyai menulis kemudian ditanggapi Kiyai lain, begitu seterusnya. ${ }^{15}$

Sedangkan LBM yang saat ini, sudah mengalami dinamika yang progresif.Ia merupakan salah satu forum diskusi keagamaan dalam organisasi NU untuk merespon dan memberikan solusi atas problematika aktual yang muncul dalam kehidupan masyarakat. Melalui forum ini, para Ulama' NU selalu aktif mengagendakan pembahasan tentang problematika aktual yang berkembang dimasyarakat, seperti masalah sosial, politik, budaya, ekonomi, kesehatan, keamanan dengan berusaha secara optimal untuk memecahkan kebuntuan hukum Islam, akibat dari perkembangan sosial masyarakat yang terus menerus tanpa mengenal batas, sementara secara tekstual tidak terdapat landasannya dalam alQur'an dan al-Hadith atau ada landasannya, namun pengungkapannya tidak secara jelas dan rinci. Oleh sebab itu, LBM senantiasa bergerak sebagai wahana kreasi penumpahan gagasan antar para Kiyai dalam memecahkan masalah keagamaan yang riil terjadi dimasyarakat terutama yang terkait dengan hukum Islam (fikih).

Kegiatan yang semula dari jawaban individual, dikomunikasikan dengan para ahli lain untuk diambil suatu keputusan kolektif (taqrir jama'i) yang oleh masyarakat dianggap mempunyai kekuatan dari sudut keilmuan dan akhirnya menjadi norma yang mengikat masyarakat secara kultural.

Selengkapnya, langkah-langkah proses pengambilan hukum dalam forum LBM, ${ }^{16}$ adalah sebagai berikut :

1). Penentuan hukum yang dilakukan LBM merupakan respon terhadap pertanyaan dari berbagai daerah, dari semua tingkatan organisasi yang sudah riil yang dilaksanakan perorangan atau masyarakat.

2). Sebelum diajukan ke tingkat LBM nasional, masalah itu sudah dibahas dalam LBM sesuai jajarannya, tapi tidak mendapatkan solusi yang memuaskan.

3). Melakukan identifikasi masalah untuk disiapkan jawabannya pra sidang LBM.

4). Mencari jawabannya dalam kitab-kitab klasik, modern atau majalah-majalah yang ditulis oleh para Ulama'/Kiyai yang diakui kredibelitas keilmuannya.

5). Setelah mendengar argumen dari para peserta LBM dengan landasan redaksi kitab yang jadi pegangannya, pimpinan membuat kesimpulan dan ditawarkan kepada peserta LBM untuk ditetapkan ketentuan hukumnya secara kolektif (taqrir jama'i).

6). Kumpulan ketetapan hukum seperti itulah yang dalam NU, popular disebut dengan ahkam al-fuqaha'.

Adapun, tugas, visi dan misi $\mathrm{LBM},{ }^{17}$ adalah pertama, melanjutkan tradisi LBM sejak NU berdiri, yaitu menjawab pertanyaan yang diajukan oleh cabang, PW bahkan PB guna ditetapkan kepastian hukum melalui taqriri. Jawaban dalam bagian ini dikenal dengan solusi masa'il al-waqi'iyyah, bercirikan pola jawaban singkat, tegas, disertai argumen tekstual dari kitab-kitab kuning yang diakui oleh empat Imam Madh-hab (Kutub al-Mu'tabarah).Kedua, merespon problem aktual yang dihadapi bangsa dan kaum muslimin secara keseluruhan.Pola kedua ini dalam setiap topik atau tema dibahas secara mendalam, melalui draff makalah

\footnotetext{
${ }^{15}$ Ibid., $\mathrm{X}$.

${ }^{16}$ Ibid., Xxxiii.

${ }^{17}$ Ibid., xxi.
} 
yang disisipkan terlebih dahulu.Dari situlah kemudian diskusi terjadi secara mendalam dan membuahkan hasil.Hasil tersebut kemudian disempurnakan dan diumumkan.

c. Referensi/kitab rujukan

Referensi atau kitab rujukan yang digunakan dalam menyelesaikan masalah dalam forum LBM NU beraneka ragam.Namun, keanekaragaman kitab referensi, tampak didominasi oleh kitab-kitab karya Ulama' Shafi'iyah dan madh-hab Shafi'i.mulai dari yang paling ringan dan kecil seperti Safinah al-Salah karya Imam Nawawi al-Banteni sampai dengan yang paling besar seperti al-Umm dan al-Majmu'. ${ }^{18}$

Lebih detilnya, berikut daftar referensi sekaligus hierarki penggunaan kitab yang dijadikan rujukan Ulama' NU dalam forum LBM :

1). Al-Umm, karya al-Shafi'i

2). Mukhtasar, karya al-Muzani

3). Al-Muhadhdhab, karya al-Shirazi

4). Al-Tanbih li al-Shirazi

5). Al-Matlab fi Dirasah al-Madh-hab, karya al-Juwaini

6). Al-Basit, al-Wasit dan al-Wajiz, karya al-Ghazali

7). Al-Muharrar dan Fath al- 'A ziz, karya al-Rafi' i

8). Al-Majmu' Sharah al-Muhadh-dhab, karya al-Nawawi

9). Al-Raudahdan Minhaj al-Talibin, karya al-Nawawi

10). Tuhfah al-Muhtaj Sharah al-Minhaj, karya Ahmad bin Muhammad bin 'Ali

11). Al-Mughni al-Muhtaj ila Ma'rifati Alfaz al-Minhaj, karya al-Khatib alSharbini

12). Nihayah al-Muhtaj Sharah al-Minhaj, karya al-Ramli

13). I'anah al-Talibin, karya al-Dimyati

14). Fath al-Muin, karya Zainudin al-Malibari

15). Bujairimi al-Fath al-Wahhab, karya Bujairimi

Selain itu ada pula kitab-kitab karya pemikir modern yang digunakan sebagai metodologi bagi ulama NU, ${ }^{19}$ seperti :

1). Al-Risalah, karya Al-Shafi'i

2). Al-Burhan, karya Al-Juwaini

3). Al-Mustasfa', karya Al-Ghazali

4). Al-Muwafaqat, karya al-Shatibi

Dalam prakteknya, penggunaan kitab-kitab metodologis itu, pada forum LBM yang dikembangkan Ulama'/Kiyai NU, tidak tegas menyertakan pembaharuan Manhaji dalam BM. Dari minimnya penggunaan kitab metodologis tersebut, tampak ada upaya desakralisasi atas madh-hab Shafi'i yang selama ini menjadi handbook Kiyai NU. ${ }^{20}$

d. Objek yang dikaji

Objek yang dikaji dalam forum LBM bermacam-macam, mulai dari hukumhukum Islam yang berkaitan dengan masa'il al-fiqhiyyah maupun masalah

${ }^{18}$ Ibid., xiii.

19 Imam Yahya, Bahthu al-Masa'il NU: Media Pemikiran Hukum Islam. Dalam http://buntetpesantren.org.(28 Mei 2009).

${ }^{20}$ Imam Yahya, Dalam http://buntetpesantren.org. (28 Mei 2009). 
ketauhidan dan tasawuf. Masalah-masalah yang dibahas, umumnya merupakan kejadian (waqi'ah) yang dialami oleh masyarakat yang diajukan kepada Shuriyah oleh organisasi /perorangan. ${ }^{21}$ Secara umum, masalah yang menjadi objek Bahthu al-Masa'il diantaranya, adalah masalah ibadah, kesehatan, teknologi, keamanan, prilaku dan moralitas, dan lain-lain.

Dari penjelasan di atas, penulis dapat menyimpulkan, bahwa objek masalah yang dikaji dalam forum LBM adalah masalah apa saja yang dicari hukumnya yang bersifat ahkam al-shar'iyyah. Jika masalah yang dibahas terkait masalah tasawuf, tentu saja masalah dibidang tasawuf yang ditinjau dari segi ahkam alshar'iyyahnya, dan seterusnya (dimensi hukumnya).

2. Aspek pada prosedur penetapan hukum Islam NU

Sejak awal berdirinya, NU telah menjadikan madh-hab Shafi'i sebagai salah satu anutan yang dominan. Meskipun, pengaruh madh-hab Shafi'i ini terlihat sangat kuat dikalangan NU, bukan berarti dalam perjalanan istinbathukum Shar'iyyah, NU menolak apalagi antipati dengan Ulama' atau madh-hab lain. Sejak dulupun para Kiyai/Ulama' NU juga tidak mengharuskan Shafi'i saja, tetapi juga merujuk pada madh-hab lain.

Namun, sebelum membahas lebih dalam bagaimana prosedur penetapan hukum Islam NU, terlebih dahulu dijelaskan apa pengertian istilah "Istinbat" dalam konteks ke-NU-an.

Pengertian istinbat al-ahkam di kalangan NU bukan mengambil langsung dari sumber aslinya, yaitu al-Qur'an dan al-Hadith, akan tetapi men-tatbiq-kan (memberlakukan) secara dinamis nas-nas fuqaha' dalam konteks permasalahan yang dicari hukumnya.Istinbat dalam pengertian menggali secara langsung dari al-Qur'an dan al-Hadith yang cenderung kearah ijtihad dirasa Kiyai NU sangat sulit, bahkan tidak mungkin dilakukan, karena keterbatasan-keterbatasan yang disadari oleh mereka.Mengatasi hak tersebut, maka istinbat dalam pengertian hanya men-tatbiqkan itulah, selain praktis, istinbat model tersebut dapat dilakukan oleh semua ulama NU yang telah memahami ibarat-ibarat kitab fikih sesuai dengan terminologinya yang baku. Oleh karena itulah, kalimat istinbat di kalangan NU - terutama dalam kerja Bahthu al-Masa'il Shuriyah - tidak popular karena kalimat itu terkenal dekat sekali dengan terminologi ijtihad.Sementara bagi Shuriyah, ijtihad adalah sesuatu yang sulit dilakukan karena keterbatasan pengetahuan.Sebagai gantinya dipakailah kalimat Bahth al-Masa'il yang artinya membahas masalah-masalah waqi'ah melalui referensi yaitu Kutub al-Fuqaha, ${ }^{22}$

Eksistensi forum BM dapat disebut sebagai evolusi dalam perkembangannya untuk sampai ketingkat melakukan Istinbat Jama'i. sejak sebelum berdirinya NU pada ahun 1926, baru pada tahun 1992 di MUNAS Lampung telah diputuskan, bahwa BM NU boleh melakukan penetapan hukum dengan kerangka bermadh-hab secara Manhaji. Wacana ini muncul karena pertama, pergumulan warga NU dengan wacana

${ }^{21}$ LTN NU, Solusi Problematika Aktual Hukum Islam, (Surabaya: LTN NU Jawa Timur dan Diantama, 2005), $\mathrm{x}$.

${ }^{22}$ Ibid., xiii. 
baru yang menuntut adanya pembaharuan disegala aspek kehidupan manusia terutama yang berkaitan dengan hukum Islam.Kedua, munculnya intelektual muda NU yang mencoba membangun paradigma baru yang secara umum bertujuan menkaji teks-teks fikih klasik dengan mengikutsertakan sosio-historisnya. Dalam praktiknya, tidak hanya mengkaji teks ansich melainkan juga menganalisis metodologi yang digunakan oleh para Ulama' terdahulu. Pasca munas Lampung, penetapan hukum Islam sudah mulai didominasi semangat dalam kerangka bermadhhab, yakni dengan mengikuti pendapat atau kerangka berfikir yang ditempuh Imam Mujtahid dari nas al-Qur'an dan al-al-Hadith.Ini dapat diartikan bahwa Ulama' NU sudah ada pergeseran alur metodologi istinbat yang terbudaya mengarah kepada ijtihad, walaupun tidak sampai pada derajat ijtihad mutlaq. Atas dasar ini pula, secara konsisten sikap bermadh-hab seperti itu ditindaklanjuti dengan merumuskan metodologi penetapan hukum Bahth al-Masa'il dalam kerangka bermadh-hab, baik secara qawlimaupun manhaji.

Bermadh-hab secara qawli artinya mengikuti hukum-hukum yang telah diambil para Imam madh-hab atau 'asab-nya yang berbentuk qawl dan wajh.Qawl artinya pendapat atau beberapa pendapat Imam madh-hab seperti Hanafi, Maliki, Shafi'i dan Hanbali yang terdapat dalam kitab karangannya maupun yang dikutip para muridnya, dan wajh berarti pendapat para ulama madh-hab tentang suatu masalah yang terdapat dalam kitab karangan mereka. Sedangkan bermadh-hab secara manhaji artinya dalam menetapkan hukum suatu masalah mengikuti kaidah dan metode yang telah ditetapkan oleh para Imam madh-hab atau mengambil jalan pikiran mereka. ${ }^{23}$

Adapun prosedur metodologis yang ditempuh dalam penetapan hukum NU, yang telah dihasilkan melalui MUNAS tahun 1992 dalam kerangka bermadh-hab secara qawli, ${ }^{24}$ yaitu :

a. Ketika jawaban bisa bisa dicukupi oleh ibarat kitab dan hanya terdapat satu qawl/wajh, maka disepakatilah qawl/wajh sebagaimana diterangka dalam ibarat tersebut.

b. Dalam kasus ketika jawaban bisa dicukupi oleh ibarat kitab dan disana terdapat lebih dari satu qawl/wajh, maka dipakailah taqrirjama'i untuk memilih satu qawl/wajh.

c. Dalam kasus tidak ada qawl/wajh yang dapat memberikan penyelesaian sama sekali, maka dilakukan prosedur ilhaq al-masa'il bi nazairiha secara jama'i oleh para ahlinya.

d. Sedangkan dalam kasus tidak ada qawl/wajhsama sekali dan tidak ada kemungkinan dilakukan ilhaq, maka bisa dilakukan istinbat jama'i dengan prosedur madh-hab secara manhaji oleh para ahlinya.

Sementara itu, jika terdapat kasus yang memerlukan taqrir jama'i, Munas juga memberikan ketentuan prosedur yang harus dilakukan, ${ }^{25}$ yaitu:

a. Mengambil pendapat yang lebih maslahah atau yang lebih kuat

b. Sedapat mungkin melaksanakan ketentuan Muktamar NU ke 1, bahwa perbedaan pendapat diselesaikan dengan mamilih :

\footnotetext{
${ }^{23}$ Wahbah al-Zuhaili, Al-Fiqh al-Islami wa Adillatuh, (Beirut: Dar al-Fikr, 1981), 63.

${ }^{24}$ PBNU, Keputusan Munas Alim Ulama' Tahun 1992, No. 01/Munas/1992, (Jakarta: Lajnah Ta'lif wa alNasr PBNU, 1992), 5-6.

${ }^{25}$ Ibid., 7-8.
} 
1). Pendapat yang disepakati oleh al-Shaikhani (al-Nawawi dan al-Rafi'i)

2). Pendapat yang disepakati oleh al-Nawawi

3). Pendapat yang disepakati oleh al-Rafi'i

4). Pendapat yang didukung oleh mayoritas Ulama'

5). Pendapat Ulama' yang terpandai

6). Pendapat Ulama' yang paling wira'i.

Dalam penetapan hukum, NU juga memakai dasar pertimbangan yang umum dipakai oleh para Ulama' yaitu maqasid al-shari'ah. ${ }^{26} \mathrm{NU}$ pernah merumuskan hal ini dalam konteks maslahah al- 'ammah, ${ }^{27}$ sebagai berikut :

a. Maslahah al-'ammah adalah sesuatu yang mengandung manfaat dilihat dari kepentingan manusia dan tidak ada nilai madarat yang terkandung didalamnya, baik meliputi jalb al-masalihatau daf' al-mafasid.

b. Maslahah al- 'ammah harus selaras dengan tujuan shari' ah yaitu terpeliharanya lima hak dan jaminan dasar manusia (al-usul al-khamsah).

c. Maslahah al-'ammah harus benar-benar untuk kepentingan umum, tidak untuk kepentingan khusus. Adapun sesuatu yang membawa manfaat dan meniadakan, yang hanya menguntungkan atau untuk kepentingan pihak-pihak tertentu, bukan termasuk maslahah al-'ammah.

d. Maslahah al-'ammah tidak boleh mengorbankan kepentingan umum lain yang sederajat, apalagi lebih besar.

e. Maslahah al-'ammah harus bersifat al-haqiqiyyah (nyata) dan tidak wahmiyyah (hipotesis). Karena itu untuk menentukan maslahah al-'ammah harus dilakukan melalui kajian yang cermat atau penilaian, musyawarah dan ditetapkan secara bersama-sama.

f. Maslahah al-'ammah tidak boleh bertentangan dengan al-Qur'an, al-Hadith, Ijma', dan Qiyas. Karena itu, setiap kebijakan yang diambil dengan dalih untuk kepentingan umum, tetapi bertentangan dengan landasan tersebut, maka harus ditolak.

Dari rumusan-rumusan metodologis di atas, dapat di ambil kesimpulan bahwa penetapan hukum dalam NU, sebagaimana dikutip Nurul Hanani, ${ }^{28}$ tidak menggali hukum langsung dari sumbernya, melainkan hanya mengeluarkan hukum dengan cara memberlakukan secara dinamis nas-nas yang telah dielaborasi ahli fikih kepada persoalan yang hendak dicari hukumnya. Dalam pola pikir NU, istilah istinbat alahkam didefinisikan sebagai suatu upaya mengeluarkan hukum shara' dengan alqawa'id al-fiqhiyah danal-qawa'id al-usuliyyah, baik berupa adillah ijmaliyyah, adillah tafsiliyyah, maupun adillah al-ahkam. ${ }^{29}$

Sedangkan istilah Ilhaq di kalangan NU, dalam penggunaannya hampir sama dengan Qiyas. ${ }^{30}$ Ulama NU mengartikan Ilhaq dengan menyamakan hukum suatu

\footnotetext{
${ }^{26}$ Ahmad al-Mursi Husain Jauhar, Maqasid al-Shari'ah fi al-Islam, Terj. Khikmawati, (Jakarta: AMZAH, 2009), xv.

${ }^{27}$ PBNU, Hasil-hasil Muktamar ke 29 Nahdlah al-Ulama', (Jakarta: Lajnah Ta'lif wa al-Nashr, 1996), 3536.

${ }^{28}$ Nurul Hanani, Ijtihad dan Taklid Perspektif KH. Hashim Ash'ari, (Kediri: STAIN Kediri Press, 2009), 77.

${ }^{29}$ Ibid., 77.

${ }^{30}$ Moh. Riva'i, Ushul Fiqih, (Bandung: PT. Al-Ma'arif, 1995), 116.
} 
kasus yang belum ada dalam kitab (kutub al-mu'tabarah) $)^{31}$ dengan hukum suatu masalah serupa yang telah dijawab oleh teks kitab, sedangkan Qiyas adalah aktivitas manyamakan hukum suatu masalah yang belum ada hukumnya, dengan persoalan yang telah diketahui hukumnya dalam al-Qur'an dan al-Sunnah. Kedua model prosedur tersebut, memiliki persamaan yakni sama-sama harus disangga oleh adanya empat softwere pendukung. Jika di dalam Qiyas ada asl, furu', hukum asl dan 'illat alhukm, ${ }^{32}$ sementara dalam Ilhaq juga harus ada softwere pendukung yaitu mulhiq, mulhaq 'alaih, hukum mulhiqdan'illat al-hukm yang sama. ${ }^{33}$

Meskipun modelnya sama, Ilhaq tetap berbeda dengan Qiyas. Ilhaq lebih ditekankan pada masalah yang parsial (juz'iyyah), sedangkan Qiyas, lebih ditekankan pada masalah yang makro (kulliyyah). Dengan kata lain, objek yang mejadi sandaran hukum dalam Ilhaq adalah kitab rujukan, sementara Qiyas merujuk kepada al-Qur'an dan al-Sunnah. ${ }^{34}$

Secara umum, mengenai contoh-contoh masalah dan produk hukum LBM melalui berbagai metode seperti di atas, dapat dilihat dalam buku yang berjudul: Solusi Problematika Aktual Hukum Islam, yang diterbitkan atas kerjasama LTN NU Jawa Timur dan Diantama Surabaya, pada tahun 2005.

Berikut adalah contoh kasus yang diangkat dalam forum LBM, yaitu berkaitan dengan masalah bagaimana hukum mengubur mayat dalam peti.Masalah ini terdapat dalam buku di atas, nomor masalah 59, halaman 60, Kep. Muktamar NU ke-4 di Semarang pada taggal 14 Rabi' al-Thani 1348 H./19 September 1929 M. Prosedur penyelesaian kasus ini, diawali dengan sebuah pertanyaan :

Soal : Bagaimana pendapat Muktamar tentang kuburan yang mengeluarkan air, dan selalu tergenang air sebelum selesai penanaman mayat. Apakah penanaman mayat dalam kuburan itu termasuk penghinaan kepada mayat?kalau demikian halnya, apakah mayat itu wajib dikebumikan di dalam peti yang dapat mencegah masuknya air? ataukah sama sekali tidak diperbolehkan menanam mayat di dalam kuburan itu?

Jawab : Memang benar, bahwa menanam mayat dalam kuburan yang mengeluarkan air, itu termasuk penghinaan kepada si mayat, dan menanam mayat di dalam peti itu hukumnya boleh, demikian menurut keterangan di dalam kitab Tuhfah, sedang di dalam kitab I'anah diterangkan apabila keadaan demikian, maka menanam mayat dalam peti itu hukumnya wajib.

Keterangan tersebut dalam Kitab Tuhfah bab "Menanam Mayat" sebagai berikut :

Artinya : "Sesuai kesepakatan Ulama, dimakruhkan mengubur jenazah dalam peti, karena temasuk bid'ah, kecuali kalau ada udhur, seperti di tanah yang

\footnotetext{
${ }^{31}$ Kitab-kitab (khususnya fikih) yang menjadi rujukan Imam madh-hab dan Ulama' madh-hab.

32، Abd al-Wahhab Khalaf, 'Ilm Usul al-Fiqh, (Beirut: Dar al-Fikr, 1978), 52.

${ }^{33}$ Nurul Hanani, Ijtihad dan Taklid Perspektif KH. Hashim Ash'ari, (Kediri: STAIN Kediri Press, 2009), 78.

${ }^{34}$ Bandingkan metode ilhaq dengan metode qiyasdalam usul fikih. Dalam qiyas, maqis 'alaihnya adalah nas-nas.Sedangkan ilhaq, yang menjadi mulhaq 'alaihnya adalah teks-teks/redaksi/pendapat-pendapat Imam madh-hab yang dikutip ulama'-ulama' fikih dalam kitab fikih.Lihat : Wahbah al-Zuhaili, Usul al-Fiqh alIslami, Juz I, (Beirut: Dar al-Fikr, 1986), 603. Bandingkan dengan 'Abd al-Hakim 'Abd al-Rahman As'ad alAs'adi, Mabahith al-'Illah fi al-Qiyas 'Inda Usuliyyin, (Beirut: Dar al-Basa' ir al-Islamiyyah, 1986), 25. Bandingkan dengan M. Yusuf Musa, Al-Madkhal li Dirasat al-Fiqh al-Islami, (Beirut: Dar al-Fikr, t.t.), 193.
} 
lembab atau gembur, berair atau adanya binatang buas yang akan menggalinya walaupun sudah padat, yang sekiranya tidak akan bisa terlindungi kecuali dengan dimasukkan dalam peti, atau jenazah yang wanita yang tidak punya muhrim. Dalam hal ini, maka tidak dimakruhkan menggunakan peti mati untuk kemaslahatan, bahkan bila diperkirakan adanya binatang buas, maka hukumnya menjadi wajib."

Sedangkan keterangan yang diambil dari kitab I'anah juz II, yaitu :

Artinya : "Dimakruhkan menggunakan peti mati kecuali semisal berada tanah yang lembab berair, maka hukumnya wajib."

Produk hukum di atas, tentu relevan sekali jika dikaitkan dengan kondisi alam masing-masing daerah di Nusantara ini.Sebut saja di sebagian besar pulau Sumatera dan pulau Kalimantan, yang struktur tanahnya berupa rawa-rawa. Menurut penulis, alasan kebolehan menggunakan peti, tidak hanya berdasar karena adanya binatang buas dan prestise manusia, tetapi lebih itu, penggunaan peti akan memudahkan dalam proses menenggelamkan jenazah kedalam lubang kubur. Sementara itu, untuk proses menenggelamkan jenazah tersebut, biasanya harus di injak terlebih dahulu oleh tukang kubur, sekaligus memasukkan tanah kedalamnya. Dari fakta itu, dapat dibayangkan, apa jadinya, jika dalam kondisi seperti itu, jenazah tidak diberi casing berupa peti, agar dapat mempermudah memasukkan ke dalam kubur dan menjaga kondisi jenazah agar tidak terinjak langsung oleh tukang kubur.

Selain contoh di atas, tentu masih banyak contoh lain yang tidak dapat dimasukkan dalam makalah ini. Namun, dapat digarisbawahi, bahwa dari sekian contoh yang ada, forum dan perangkat dalam LBM senantiasa menggunakan hierarki dan kerangka metodologi sebagaimana dijelaskan di atas.

Adapun istilah "Ijtihad" menurut NU hanya berlaku bagi ijtihad mutlaq mustaqil, sehingga mujtahid pada tingkat itu dapat disebut sebagai mujtahid.Sedangkan tingkatan dibawahnya, termasuk dalam ketegori taklid.Dengan demikian jelaslah bahwa dalam prinsip pemikiran hukum, NU tidak menyatakan diri sebagai golongan mujtahid tetapi mengakui dirinya sebagai kelompok muqallid. Aktualisasi prinsip taklid dalam pemikiran NU dapat disimpulkan dari ungkapan berikut :

“...Meskipun sudah mahir, sudah hafal puluhan Hadith dan tahu persis kelemahan serta kekuatan dalil-dalil yang dipergunakannya, bukan berarti sudah lepas dari tingkatan taklid. Sebab persyaratan yang diperlukan bagi orang yang tidak mau menerima predikat taklid tidaklah sederhana.Karena itu NU tetap mendidik warganya untuk tidak bersikap seperti orang yang sudah mampu berijtihad sendiri. ${ }^{35}$

Dari pemikiran ini, maka sikap NU, bertaklid kepada Imam madh-hab secara manhaji bukanlah suatu hal yang buruk, karena hal ini "sama dengan" peringkat mujtahid muntasib bi al-madhhab. ${ }^{36}$ Klaim istilah "sama dengan" peringkat mujtahid

\footnotetext{
${ }^{35}$ Ahmad Siddiq, Khittah Nahdliyyah, (Jakarta: PBNU, t.t.), 40.

${ }^{36}$ Mujtahid Muntasib adalah mujtahid yang kemampuannya masih terbatas (ralatif), masih menggunakan pola atau metode yang diciptakan atau dirumuskan oleh mujtahid lain (yang mutlaqmustaqil). Imam al-Ghazali misalnya, sudah tergolong mujtahid, tetapi masih menggunakan metode ijtihadnya Imam al-Shafi' i, maka Imam al-Ghazali disebut mujtahidmuntasib ila al-Imamal-Shafi'i (berhubungan dengan madh-hab Imam Shafi'i).
} 
muntasib bi al-madhhab ini, menurut penulis, sebagaimana menganalisa ungkapan di atas, bukan berarti mampu mencapai peringkat itu, melainkan hanya disejajarkan dengan peringkat tersebut.

\section{E. Kesimpulan}

NU berdiri di Jawa Timur, pada tanggal 31 Januari 1926. Organisasi ini didirikan oleh KH. Hashim Ash'ari, KH. Wahab Hasbullah dan KH. Bisri Samsuri.

Corak pemikiran hukum Islam NU, yaitu menganut madh-hab Shafi'i.Corak ini menjadi karakter NU dalam menentukan dan menetapkan hukum terhadap masalah yang dicari hukumnya.

Adapun epistemologi istinbat al-ahkam, NU memiliki 2 aspek. Aspek tersebut yaitu:

1. Aspek prosedur teknis struktural, meliputi : para Kiyai/Ulama' NU, forum Bahth alMasa'il, referensi, dan objek yang dikaji.

2. Sedangkan aspek epistemologi istinbat al-ahkam, NU menggunakan metode ilhaq almasa'il bi nazairiha. Ilhaq al-masa'il bi nazairiha adalah menyamakan hukum suatu kasus yang belum ada dalam kitab-kitab fikih yang menjadi rujukan, dengan hukum suatu masalah serupa yang telah dijawab oleh teks dalam kitab-kitab tersebut dengan berpatokan pada unsur-unsur/rukun di dalamnya. Unsur-unsur/rukun tersebut, yaitu mulhiq, mulhaq'alaih, hukummulhiqdan'illat al-hukm yang sama. Teknisnya NU memiliki kerangka metodologis secara qawli sebagai berikut :

a. Ketika jawaban bisa dicukupi oleh ibarat kitab dan hanya terdapat satu qawl/wajh, maka disepakatilah qawl/wajh sebagaimana diterangka dalam ibarat tersebut.

b. Dalam kasus ketika jawaban bisa dicukupi oleh ibarat kitab dan disana terdapat lebih dari satu qawl/wajh, maka dipakailah taqrir jama'i untuk memilih satu qawl/wajh.

c. Dalam kasus tidak ada qawl/wajh yang dapat memberikan penyelesaian sama sekali, maka dilakukan prosedur ilhaq al-masa'il bi nazairiha secara jama'ioleh para ahlinya.

d. Sedangkan dalam kasus tidak ada qawl/wajhsama sekali dan tidak ada kemungkinan dilakukan Ilhaq, maka bisa dilakukan istinbat jama'i dengan prosedur madh-hab secara manhaji oleh para ahlinya.

3. Sedangkan jika terdapat kasus yang memerlukan taqrir jama' $i$, ketentuan prosedur yang harus dilakukan, yaitu:

a. Mengambil pendapat yang lebih maslahah atau yang lebih kuat

b. Sedapat mungkin melaksanakan ketentuan Muktamar NU ke 1, bahwa perbedaan pendapat diselesaikan dengan mamilih :

1). Pendapat yang disepakati oleh al-Shaikhani (al-Nawawi dan al-Rafi'i)

2). Pendapat yang disepakati oleh al-Nawawi

3). Pendapat yang disepakati oleh al-Rafi'i

4). Pendapat yang didukung oleh mayoritas Ulama'

5). Pendapat Ulama' yang terpandai

6). Pendapat Ulama' yang paling wira'i.

Lihat : Muchith Muzadi, NU dan Fikih Kontekstual, (Yogyakarta: LKPSM NU DIY, 1994), 10; Nurul Hanani, Ijtihad dan Taklid Perspektif KH. Hashim Ash'ari, (Kediri: STAIN Kediri Press, 2009), 79. 


\section{F. DAFTAR PUSTAKA}

As'adi, 'Abd al-Hakim 'Abd al-Rahman As'ad,Mabahith al-'Illah fi al-Qiyas 'Inda Usuliyyin, Dar al-Basa' ir al-Islamiyyah: Beirut, 1986.

Daman, Rozikin, Membidik NU, Gama Media: Yogakarta, 2001.

Haidar, M. Ali, NU dan Islam di Indonesia; Pendekatan Fikih dalam Politik, PT. Gramedia Pustaka Utama: Jakarta, 1994.

Hanani, Nurul, Ijtihad dan Taklid Perspektif KH. Hasyim Asy'ari, STAIN Kediri Press: Kediri, 2009.

Jauhar, Ahmad al-Mursi Husain, Maqasid al-Shari'ah fi al-Islam, Terj. Khikmawati, AMZAH: Jakarta, 2009.

Khalaf, Abd al-Wahhab, 'Ilm Usulal-Fiqh, Dar al-Fikr: Beirut, 1978.

LTN NU, Solusi Problematika Aktual Hukum Islam, LTN NU Jawa Timur dan Diantama: Surabaya, 2005.

Malik, Dedy Djamaluddin, at., al, Zaman Baru Islam Indonesia: Pemikiran dan Aksi Politik Abdurrahman Wahid, M. Amin Rais, Nurchalish Madjid, dan Jalaluddin Rakhmat, Zaman Wacana Mulia: Bandung, 1998.

Musa, M. Yusuf, Al-Madkhal li Dirasat al-Fiqh al-Islami, Dar al-Fikr: Beirut, t.t.

Muzadi, Muchith, NU dan Fikih Kontekstual, LKPSM NU DIY: Yogyakarta, 1994.

PBNU, Hasil-hasil Muktamar ke 29 Nahdah al-Ulama', Lajnah Ta'lif wa al-Nashr: Jakarta, 1996.

PBNU, Keputusan Munas Alim Ulama' Tahun 1992, No. 01/Munas/1992, Lajnah Ta'lif wa al-Nasr PBNU: Jakarta, 1992.

Riva'i, Moh.,Usulal-Fiqh, PT. Al-Ma'arif: Bandung, 1995.

Salam, 'Abd, Sejarah dan Dinamika Sosial Fikih Reformis dan fikih Tradisionalis di Indonesia, dalam Jurnal Islamica, Volume 4, No. 1, Program Pascasarjana IAIN Sunan Ampel Surabaya: Surabaya, 2009.

Shodiq, Ja'far, Pertemuan antara Tarekat dan NU, Studi hubungan Tarekat dan Nahdlatul Ulama' dalam Konteks Komunikasi Politik 1955-2005, Pustaka Pelajar: Yogyakarta, 2008.

Siddiq, Ahmad, Khittah Nahdliyyah, PBNU: Jakarta, tt.

Yahya, Imam, Bahtsual-Masa'il NU: Media Pemikiran Hukum Islam. Dalam http://buntetpesantren.org.(28 Mei 2009).

Zahrah, Imam Muhammad Abu, Aliran Politik dan Aqidah dalam Islam, Logos: Jakarta, 1996.

Zuhaili, Wahbah al-, Al-Fiqh Al-Islamiwa Adillatuh, Dar al-Fikr: Beirut, 1981.

Zuhaili, Wahbah al-, Usulal-Fiqh al-Islami, Juz I, Dar al-Fikr: Beirut, 1986. 